\title{
GRADUATED SOVEREIGNTY VIS-À-VIS ASPIRATIONS: EDUCATION FOR THE ADIVASI AND CULTURAL POLITICS IN THE BARIND REGION OF BANGLADESH
}

\author{
Shaila Sharmeen ${ }^{1}$ \\ Mohammad Tareq Hasan ${ }^{2}$ \\ S. M. Arif Mahmud ${ }^{3}$
}

\begin{abstract}
This article is concerned with the meaning of education for Santal and Munda communities, living in the Barind region. The aim of this paper is to document the narratives of Adivasis' on education. What do they mean by education? What kind of situation did they experience in formal education? How they respond to the existing form of education. The article is written based on ethnographic material drawn from 8/9 months of frequent visit in the field of study. Data was collected by using semi-structured questionnaire, observation and participation. To Adivasis of Santal and Munda communities, education means to fight the mainstream society back, to act confidently, erase the stereotypical images they are labelled by the dominant group, and to get freedom from poverty; aspirations to overcome the conditions of graduated sovereignty and cultural politics. To consider the qualitative matter of social mobility, namely the aspiration in both the individual and community levels, the article proposes to look beyond the existing dominant analytical frame of educational access and exclusion. The analytical tools were developed following Appadurai's concept of aspiration and Ong's idea of graduated sovereignty. This article is a critical assessment of the marginal communities' formal education and development and will contribute to ethnographic intervention in social anthropology and development studies, and contemporary debate on politics of education.
\end{abstract}

Keywords: Adivasi, aspiration, Barind, education, graduated sovereignty

1 Shaila Sharmeen, PhD is Professor, Department of Anthropology, University of Dhaka. Email: shaila_1976@yahoo.com [Corresponding author]

2 Mohammad Tareq Hasan, PhD is Assistant Professor, Department of Anthropology, University of Dhaka. Email: tareq.hasan@du.ac.bd

3 S. M. Arif Mahmud, PhD is Associate Professor, Department of Anthropology, University of Dhaka. Email: arif_et1226@du.ac.bd

Social Science Review [The Dhaka University Studies, Part-D], Vol. 37, No. 2, December 2020 


\section{Introduction}

Under Article 23A of the Bangladesh Constitution, it is stated that 'the State shall take steps to protect and develop the unique local culture and tradition of the tribes, minor races, ethnic sects and communities' (emphasis added). Demographic marginal positions and the state denial to recognize them as 'indigenous people' ${ }^{1}$ in the constitution coupling with the colonial representation of them as 'savages' devoid them of any substantial benefits from state sponsored affirmative action. The Adivasi are officially known as 'small ethnic community' and constitute some 1.6 million people making up only 1.8 percent of Bangladesh's populations while other sources state that the total number is considerably higher. The Christian missionaries and non-government organizations came forward in distinct phases and offered them opportunities regarding education. Overall, the experience of the Adivasi in the Barind region reflects a form of 'graduated sovereignty' (Ong, 2000) where Adivasi are systematically marginalized through educational initiatives and cultural politics. However, an analytical lens finds Adivasi's 'capacity to aspire' (Appadurai, 2004) in making a 'good life' (Moore, 1990; Fischer, 2014) overturning their marginal position in the social spectrum of cultural politics.

A range of scholars in economics and development studies (Islam, 2004; Latif, 2004; Ahsan \& Mullick, 2013) argued that it was not until the 1990s when the literacy rate started to increase due to policy/programme interventions from the State and non-government organizations. Nonetheless, the standardized/general meaning of education, which shaped the ideology of formal institutional education, has its roots in colonial discourse. The formal educational system was created, chiefly, to maintain the social standards of a certain class and gradually created an inclusively excluding situation where Adivasi were somewhat incorporated into formal education which appeared alien to them.

The idea of education as a central 'social good' or a tool for personal and collective development or a basis for individual empowerment and a social and political transformation has a long history (Jeffery et al., 2004; Ciotti, 2006; Froerer 2012; 2015). Adivasi - who do not share a worldview built on ranking and competition -often find it hard to cooperate with this meaning view of education. Reasons are not only infrastructural, but ideological too. When compared to Bengalis, it is observed that their heroes like Birsa Munda and Kanhu Murmu and Sidhu Murmu are pictured to be rebellious, with bows and 
arrows, ready to fight back, rather than being enlightened and live in cooperation with the state, or, in this case, the education system.

The public and popular (mis)representation of the Adivasi as savage, backward, and underdeveloped continued since the colonial era. In recent years, much research on education of the marginal groups as the Adivasi have been published (Sarker \& Davey, 2009; Sharif, 2014). Besides showing poverty as a main reason for the low rate of literacy, many publications have addressed developmental issues concerning education and its impact on these communities (see Sarker \& Davey, 2009; Sharif, 2014). But these studies engulfed mostly on statistical data and an economic approach avoids writing about the ideological uses and consequences of education amongst the Adivasi, the article is intended to fill this gap.

The aim of this paper is to perceive the meaning of education from Adivasi point of views. Hence, this article sheds light on Adivasi experiences of formal school education in the Barind region of Bangladesh. With a historical tracing of the discourse of formal education in the forms of colonialism, and efforts of the postcolonial nation states, the article analyses the overarching cultural politics. The historical analysis depicts forms of graduated sovereignty in the Barind region and the article eventually reveals aspirations of the marginalized towards a 'good life'. Hence, the article is an attempt to overturn the historical legacy of colonialism and representation of the Adivasi as incompetent having no 'capacity' to aspire.

The article is written based on insights from conversations with parents and students to reveal the ways Adivasi use formal education for their cause in the cultural milieu of the locality and strive towards their aspirations despite the contradictions, dilemmas, and structural-ideological barriers created by the nation-state. The article contends, it is high time to look beyond the existing dominant analytical frame of educational access and exclusion.

To highlight the voice of the Adivasi that the development planners/policymakers generally ignore ethnographic insights from two communities, the Santal (Christianized community) and the Munda (Sanatan Hindu community) are presented. The material for this article is collected through frequent visits in the field of study over a period of 9 months during 2019. Data collection was aided by long conversations with parents, teachers, and students, and observation of schools in Naogaon and Rajshahi. 
This article is organized in seven sections. After the brief introduction of this section, the arguments, theoretical framework, and method are presented. Section three introduces the context of the study and has a discussion on the current state of education and literacy rate. Section four focuses on the historical trajectory of Adivasi education initiatives in terms of policy interventions (colonialism, missionary, NGOs, infra- state bodies, etc.) and its critics. The historical analysis guided us to find the root of cultural politics of education in separate phases of time. Section five explores why schooling failed and narrates people's everyday experiences of education in the Barind that is based solely on the ethnography. Section six presents ethnographic observations and instances of aspiration of the Adivasi - who overcome the structural-ideological barriers and use 'education' as means/tools for a 'good life'. Finally, section seven provides some concluding observations.

\section{Arguments and Methodology}

\section{The problem and theoretical perspective}

Education is considered one of the major thrust areas for sustaining Bangladesh's impressive economic growth. Educational investment has thus received special policy-level attention. Recent ethnographic fieldwork in the Barind region has raised some concerns about the ways people at the margin encounter formal education.

South Asian scholars engaged in development and education debates have two distinct views. Some scholars (Sen, 2001; Drèzeand Sen, 2013) claim that formal education improves the position of previously disadvantaged excluded marginalized people, and helps to increase skill, knowledge, and freedom. Others argue that without ensuring equity on distributing material assets within society, formal education is likely to be only partially successful in raising the social standing and economic position of marginalized groups (Jeffrey, Jeffery, \& Jeffery, 2004; see also Sundar, 2010; Froerer, 2015). In Bangladesh, generally, scholars who work on the marginalized Adivasi peoples' education and development claim that poverty, and less scope for acquiring stable, well-paid, and white colour jobs demotivated them to continue further studies. Poor socioeconomic environments often hinder the risk for investment of cash in such matters (Sharif, 2014). Some other studies argued that elimination of structural limitations such as 'availability, affordability, and accessibility' can speed up 
their incorporation in formal education (Sarker \& Davey 2009). Nevertheless, these studies argued that the current form of education failed to contribute much to their existing life. While analysing the correlation between livelihood patterns and education attainment, it is found that, despite poverty there is a rising trend in educational enrolment in primary level. Further queries and hours of conversation gives us an indication that there are many people in these communities who have a zest for education and are willing to imagine a new meaning of education. This growing enthusiasm is considered as aspirations of the people at the margin.

The aim of this study is to document the narratives of Adivasi (Santal and Munda) perspective on education so as to ascertain the meaning of education to them. The underlying premise is that there are spirals of interconnected loops that limit the educational/development potentials of the marginal population. The aim of this study is to look beyond the statistical data and economic approach and consider the qualitative aspects of social mobility namely the aspiration in both individual and community level. ${ }^{2}$

The article will explain, how aspirations of people navigate the social, cultural, and economic contexts and generate new modes of existence beyond hegemonic ideas of a 'good life' - overall economic development of an individual, family, locality, or the country, so to speak. Appadurai (2004) regarded aspiration as 'cultural capacities, oriented towards the future, related to wants, preferences, choices, and calculations'. Based on his work among the slum dwellers and propoor housing activists in Mumbai, India, Appadurai insisted that imagination/aspiration is a collective practice. Following Appadurai, it is agreed that there are 'constraints' that shape ideas of the future, and that the 'capacity to aspire' is varied. However, the article departs from him in treating the capacity as a group dynamic, for it is believed, the capacity to aspire is individualized and fragmented - as the life stories described in this article will illustrate.

In the Barind region, though availability and accessibility of schooling and scope for using benefits create avenues taking the hegemonic path towards development, overall cultural politics - the effects of majority-minority cultural divide -entitles the members of the majority group certain benefits that the minority groups are excluded from (Evans, 1998; Haan, 1998) - leads to lesser possibilities for the Adivasi communities as reflected by the enrolment rate, and socio-economic situation. For instance, though Adivasi workers are endowed with productive capacities as like Bengalis, there exists difference in earnings and 
they remain unable to convert 'human capital' into higher income (Shafie \& Kilby, 2003). As such development-oriented approaches' economic focus and treatment of education as something that would improve 'employability' of the Adivasifail to capture the overall cultural politics, hence, the article seeks to reveal the Adivasi aspirations and their views about education.

In a condition of graduated sovereignty - i.e., certain segments of the population are subjected to different modes of governing (Ong, 2000) - where the Adivasi communities faced modes of governance that always positioned them in a position of inferiority leading to unequal access to resources, - how do the Adivasi people strive towards for fulfilling their aspirations? The ethnographic narratives will shed light on distinct aspects of the query herein below.

\section{Methodology}

Information for this article is gathered through intensive fieldwork of 9 months during July 2019 to March 2020. Along with participant-observation, in-depth discussions were conducted in the two villages, Chanduria and Khaspara concentrating on the Adivasi from the Santal and the Munda community. Interlocutors were Santal and Munda parents and their children in households, specifically, men or women aged between 15 and 60 . The discussion notes were written up in Bangla within twenty-four hours of the conversation, later these accounts were translated into English. The aim was to record their discourses about how they perceived education and about their relation within the social spectrum. For collecting a 'true description' as to what were discerned, sometimes participation as a method was also employed (see Scheper-Hughes, 1992).

\section{Research Context and the People}

This article focuses on the two villages of Rajshahi and Naogaon District. The Santal village Chanduria is under the Tanore Upazila of Rajshahi district and the Munda village Khaspara is under the Niamatpur Upazila of Naogaon district, situated in north-western Bangladesh. The northern part of Bangladesh is commonly known as the Barind region, which covers the majority of the greater Dinajpur, Rangpur, Pabna, Rajshahi, Bogra, Joypurhat and Naogaon districts of the Rajshahi division. The Barind region was formerly a part of PundravardhanaBhukti, the eastern province of the vast Maurya empire of ancient India that covered virtually all northern Bangladesh. The capital of the province was Pundranagar, which is now known as Mahasthangar, and lies in the Bogra district (Ali, 1998). 
Generally, the Barind region is rather hot and semi-arid and at a higher elevation than the adjoining floodplain areas. Agriculture depended on monsoon rainwater in the past, and so, only one crop was cultivated there, and the tract suffered from a food deficit. The Barind Integrated Area Development Project (BIADP) was started in the mid-1980s to develop groundwater irrigation in the area. ${ }^{3}$ As a result, agricultural production has increased, and the demand for labour and the area has enjoyed a food surplus.

The Barind region is composed of multi-ethnic groups, inhabited by Bengalis and 18 Adivasi communities. ${ }^{4}$ The Adivasi live scattered in different villages of this region. The Santal is the largest ethnic group of Rajshahi. ${ }^{5}$ They were the earliest immigrants in Radha (in West Bengal), the forests of adjacent Bihar (Jharkhand) and Orissa, and Chhota Nagpur, India. The language of the Santals, Santali, belongs to the Austro-Asiatic language family. Before the dominance of Christianity in the locality the Santal practiced their age-old religion, 'hordhorom' (human religion) or 'Santal dhorom', with a growing number of Christian populations, there are few people following their age-old tradition. The Munda is small ethnic group compared to the Santal. ${ }^{6}$ Azamgarh (eastern Uttar Pradesh of India) was the ancient residence of the Munda (Roy, 1912). Approximately two centuries ago, one of the ancestral groups of the Munda from Chotonagpur, Ranchi, India settled down in different districts of the Barind region (Sharmeen, 2015). In the Mundari language, Munda means 'headman of the village' (Roy, 1912). A Munda identifies himself as horo-honka, meaning 'man'. The Munda practice Sanatan Hindu Dharma. They are also linguistically associated with the Austro-Asiatic language group. The Santal and The Munda are generally bi-lingual people.

Most of them mainly worked as tenant cultivators or wage labourers for the Bengali of the locality who were mostly from the Muslim community. ${ }^{7}$ Over the years they have been forced to experience a powerful sense of social, political, and economic exclusion, lack of recognition, fear and insecurity, loss of cultural identity, and social oppression (Barkat, Hoque, Osman, \& Halim, 2009; Dhamai, 2014; Halim, 2015). These rough conditions began to change after the introduction of deep tube-wells (DTWs) in the 1980s, increasing rapidly, through to the 1990s, causing significant changes in the agricultural sector. Economic and political relationships began to transform in the villages (Sharmeen, 2014). 
The introduction of Deep Tube-wells had enabled an intensification of agriculture that included triple cropping, which resulted in commercialization of rice agriculture and higher demand for agricultural labourers. In addition, there are several developmental schemes by the government and NGOs of which the Adivasi demand a share of the benefits, and their increased participation in electoral politics have enabled them to gain certain negotiating powers as they developed connections with government offices and political parties (Sharmeen, 2013).

However, when it comes to education, most of the Santal and Munda have not had much access to mainstream education. While the literacy rate throughout Bangladesh is soaring, the same cannot be said for the marginalized communities in the Barind Region of north western Bangladesh. Education has been one factor discriminating against at least 30 million people. In a study by the Manusher Jonno Foundation (2016), it was revealed that the primary enrolment rate among marginalized communities is 69.30 per cent compared to about 78.48 per cent in the rural areas of the country. Similarly, the secondary enrolment rate is 58.67 per cent among the marginalized communities, with this rate being 72.28 per cent among the poor households of the rural areas. Overall, the average literacy rate is just 28.40 per cent amidst the marginalized communities, with the national literacy rate of 72.89 per cent. These numbers reveal that these ethnic communities are yet to substantially benefit from the existing educational model and show limited, if not zero, success of existing education policies.

The literacy rate in the Barind region has failed to considerably increase over time, owing to the absence of proper access to education, or its substandard quality. Lack of primary schools in a favourable location, truancy of teachers, flawed infrastructure, and lack of toilets, furniture, blackboards, and educational materials show the dire standards of education. Poverty has been proven to be causally linked to the low literacy rate, with the transportation costs being a huge burden, in addition to hunger, malnutrition and ill health.

A survey was conducted in Chanduria and Khaspara villages, among the Santal and Munda communities, respectively. Of the respondents in 135 Santal households, 61.6 per cent have enrolled in educational institutes at any stage of their lives. Of the 61.6 per cent, as much as 24.8 per cent are still pursuing their education at school, while the rest have dropped out at different grades between 1 and 10, mostly between grades 8 and 12. 55.7 per cent of 127 Munda households have been recorded to have received some form of education, with 24.9 per cent 
are still enrolled in different grades. A pattern has been seen in the case of withdrawing oneself from educational institutes without completing degrees. This has been combined with an understanding of their ability to write names, read letters/books/newspapers, and write letters. For a greater understanding, information related to their enrolment status in educational institutes to the types of educational institutes they have access to were collected. It is clear from the aforementioned data that a substantial part of the population in the study villages is within the reach of education.

Belonging at the bottom of the society, they are not allowed in the 'private sphere' of the Bengali majority. The Bengali treat them as unclean and polluted, prohibiting them to eat and sit together (Shafie \& Kilby, 2003; Ali \& Shafie, 2005; Islam, 2014). The overall situation shows that the cultural politics of the Barind region is related to the educational opportunities of the Adivasi. This is inevitable for the ethnic minority groups living in many countries of the world (Macias, 1996). Taking these factors into account, this study has focused on the underlying aspects of education and development of the Adivasi groups of the Barind region in Bangladesh.

\section{Educational Initiatives and the Adivasi Groups: Colonial Legacy and Postcolonial Predicament}

Forms of education that are prevalent in a country have historical roots and it corresponds with other cultural ideals of the land changes over time (Mannheim \& Stewart, 1962). Looking back in history it is found that that in the Indian Subcontinent the 'vital school knowledge' carries colonial stress (Kumar, 2005). Even though, it is often thought that the end of colonialism marks the end to coloniality, present-day school knowledge of former colonies bears the stress of colonialism on culture and society. 'What is worth teaching' carries a colonial view of society.

In the colonial times, the enlightened outsiders, i.e., the colonizers, specifically the missionaries and British officials developed an education system. For them, the skills and knowledge of the locals did not appear as fit for a proper education system. Once the colonists left, their views were carried forward by 'educated ones'. In the post-colony, for the masses, educated natives reappeared as the 'enlightened outsiders'. They do not challenge the colonial educational model. 
Colonizers did not allow the inclusion of local knowledge and cultural forms in the curriculum as in the colonial epistemology local knowledge and culture were deficient (Kumar, 2005). Hence, the school curriculum was far from fit to the local contexts. The dissociations were furthered by emphasizing education in the language of the colonizers. Moreover, education in the colony created division as only a handful number of the locals were included in the program to make them as participants of the administration while the labouring masses were set apart. Education enabled these people to place themselves above the masses. Over the years, indigenous skills, crafts, arts, and knowledge faced ignorance and became irrelevant to education.

At the centre of the colonial enterprise, one can find a relation of dependence. The relationship was modelled as an adult-child relationship. The colonizer took the responsibility of raising the incapable Indians; hence the education was necessary to arrange facilities to introduce the backward into 'new ways of acting and thinking' (Kumar, 2005). The colonial administration's interests in educating the people of India gained substantial attention in 1813 after the new Charter of the East India Company provisioned for expenditure on institutions of learning. However, it was following their earlier attitudes of general administration. The emphasis on education was philosophically aligned with liberalism, like their emphasis on private property rights (Macpherson, 1962; 1977). At the background of the British initiatives were upholding the English trading interests changing its 'rhetoric from profit for itself into service of the empire' (Kumar, 2005, p. 28).

Emphasis on education in turn involved the already dominant groups in their administration for support, a civil society was formed among the natives. Gradually, coercion was replaced by socialization. In this process, education played a crucial role along with 'liberal-economic and political doctrines, paternalism and evangelicism' (Kumar, 2005). It becomes clear when with the identification that the perceived rationale behind the colonial administration's effort to spread education was to impart an appreciation of being governed well, which would in turn ensure the law and order of the colony (Kumar, 2005). Education had a moral agenda besides the administrative agenda (Walsh, 1983; Kumar, 2005). This agenda and the paternalistic attitudes of the British administrators were later carried out by the native elites as India progressed towards independence. 
The logic educational program continued in the region once colonialism ended. Missionaries, NGOs, and the government took up initiatives that proved to be marginalizing for the socially marginal groups like the indigenous communities. All the initiatives are taken to incorporate the marginals in the majoritarian ideology of education which had less and less positive impacts (see Sarker \& Davey, 2009; Begum, Parveen, \& Chakma, 2018). A summary will evince.

One of the bodies that focus on education for the marginal communities are the Christian missionaries. The Christian community, comprising of only about 0.5 per cent of the 160 million Bangladeshi citizens, however, the missionaries have made itself known, not for spreading Christianity, but for its notable contributions towards the cultural and economic prosperity of Bangladesh. Christian missionaries in Bangladesh extended their charity-based approaches to the remotest regions of the country, establishing missions in the impregnable jungle and hilly areas of the Chittagong Hill Tracts, Garo Mountains, and isolated islands and in the remote northern indigenous villages. With every Church built, a primary school was founded. Many children in the Barind region have benefitted from this initiative. After finishing primary school, the Church helps prospective children with admission to public high schools, bearing the expenses for accommodation, food, clothes, and other educational necessities. However, it is to be noted, that those marginalized communities who agree to convert into Christianity, like the Santals, are prioritized in accessing these initiatives.

While providing basic education to the marginalized communities, the church also leads in the educational sector, through prestigious schools and colleges, like The Notre Dame College, considered one of the best, if not the best, and reputed schools like St. Joseph Higher Secondary School and St. Gregory's High School. The goal of these altruistic missionaries is to give equal priority to their students, regardless of grades or GPA. The government, however, wants students to be enrolled according to GPA, leading missionaries to face a great deal of trouble enrolling marginalized students, hence causing them to defy government orders to some extent.

Besides, with the aim of traditional development and humanitarian assistance, NGOs started taking parallel roles with the Christian Missionaries. Soon after they had shifted the focus on the need for 'upliftment' of the Adivasi. In this regard, they undertake advocacy and empowerment type work and began projects like cash distribution as a means of a loan, aged people education, and school 
establishment near Adivasi villages for the children of below 6. Schools are designed to prepare Adivasi children for getting admission in the government-run school. The children learn Bangla, English, and elementary math from a Bengali teacher to compete for the majoritarian. BRAC, a leading NGO of Bangladesh was among the pioneers that have played a leading role in the education of Adivasi since the 1990s. They tried to appoint Adivasi young adults as a teacher and became successful in some cases. Reports suggest that the children feel comfortable while learning if they have a teacher from their community (Minj \& Khakshi, 2015). Communication between teachers and students is much easier if the language is the same, whereas children face difficulties if the teacher is from the Bengali community.

Several initiatives were undertaken by the Bangladeshi government over the last 30 years and these have overall increased school attendance. ${ }^{8}$ However, the disparity still exists. While the World Education Forum focuses on improving primary education for marginal groups through expanding childcare, ensuring all children receive a good quality education, meeting children's learning needs, and eliminating gender discrimination (UNESCO, 2005). Though the Bangladesh Education Policy 2010 pledge for educating all, the marginal communities are yet to fully benefit from government/non-government efforts as the program or the teachers do not completely realize the needs of the communities (Duflo, 2012; see also Begum et al., 2018).

Besides poverty, Sarker and Davey (2009) specified that a lack of schools and educational facilities restrict the indigenous groups from availing benefit from the existing opportunities of education. As minority communities, the experience of social, political, and economic exclusion and their overall inferior status in the social spectrum translates into their reluctant participation in the classrooms. One of the interlocutors from the Santal community, Arun Hasda (40) recalled how he felt humiliated when a teacher of his class praised him by denouncing his cultural identity: he shared his classroom memory in the following manner:

Though the number of students in our time from our community was very few, Adivasi students like me were not comfortable in the school environment. We used to sit in the corner due to peer pressure as we were uchut (in a sense of unclean/polluted) to them. To continue my education, besides poverty I had to struggle to endure such kind of humiliation. When I was doing well in studies my teachers used to tell me how I got the brains by eating only snakes and frogs. 
He may have been praising me, but I felt low as the class burst into laughter. Not only from the teachers did I have to hear it, but from different people for a long time. (Discussion at Chanduria, Rajshahi August 20, 2019)

The experience of Arun Hasda stands for the effect of the colonial hegemonic discourse which consciously or unconsciously influenced teachers to tell off Adivasi students in front of other majoritarian students, often a major cause of drop out.

Colonial textualization of the term, 'tribe' as 'junglee', 'backward', 'frog-andsnail-eaters' have created an ideology, that has survived and still seems dominant in current public discourse (see Debnath, 2011). ${ }^{9}$ The following excerpt from Father Timm's (1991, p.16) article shows the mental and attitudinal representation of the Bengali people towards the Adivasi of North-western Bangladesh, which may substantialize this claim:

The attitude of Bengal to Adivasi is based on culturally inherited stereotypes of Adivasi as primitive or jungle people, even as head-hunters (as indeed some of them were in the past). They do not speak Bangla correctly and their religion and culture is regarded as inferior. They are migratory people of no permanent abode. For all those reasons they do not really belong in Bangladesh.

In this present digital era, many educational blogs are still disseminating the priorly established knowledge to presenting Adivasi of Bangladesh. ${ }^{10,11}$ In such a representation, the ethnic 'Other' has been portrayed as a noble savage, who needs development. Policymakers adopted these stereotypes in terms of development policies. Adivasi are often blamed for the lack of educational progress. The categorization of Adivasi as backward, poor, ignorant, illiterate, and blind fate often serves as an excuse for not providing school by the government. In a different vein, this discursive framework capitalized by the NGO's and the Church by providing preschool educational facilities in the Adivasi villages.

Hence, the colonial history of educational initiatives is concealed under a discursive framework produced by colonial knowledge. A similar discursive framework carried on through the post-colonial era. Colonial (mis)representations of Adivasi were circulated through published reports, compiled by post-colonial authors. Colonial representation aimed to differentiate the 'tribal people' from the mainstream societies into fixed categories and thus fix one's identity (Cohn, 1968; Bates, 1995; Skaria, 1997). In the post-colonial era, such representations 
persisted, reproducing the hierarchical power relations between the administrators and the indigenous people (Foucault, 1972).

On this backdrop, the article focuses on the social terrain of marginalization that the Adivasi navigate to make a good life for them as sketched out in the rest of the paper.

\section{The Consequences of Schooling: Graduated sovereignty in the Barind}

This article focuses, chiefly, on how the Santal and the Munda experienced mainstream education. And their perception, i.e., what education means to them? So far, it has been discussed that the opportunities attainable to these communities bears a colonial legacy of oppression and disregard. Now, the article turns to explain how the marginal indigenous communities experience education. Three ethnographic fragments and insights are used to reveal how cultural politics around education has led to differential impacts on the marginalized as opposed to the Bengali population - a form of graduate sovereignty (Ong, 2000).

\section{Education for becoming shovvo}

In a group discussion with twelve Munda parents between ages 30 and 50, the discussion revolved around - 'what is education?' The conversation covered a wider range of topics regarding education. One of the aspects that came at the front at the beginning was the fact that it was not until the 1990s when their village got a preschool. The school was run by a project of BRAC - a leading NGO of the country. The only government school they had was 3 kilometres away. At that time only two boys got the chance to be admitted in that school. BRAC's pre-primary school was the one where most of the Munda children first met schooling.

In the discussion, Noresh Munda (50) - who has never been to a formal school is insightful about the Adivasi discourse on which formal schooling was introduced. He told now he could only write his name as he learnt to read and write on the elderly literacy project in early 90 s. He remarked,

We were junglee (wild) in the past. After working in the fields, we returned home and consumed alcohol all over the night. If you saw us then, you would not get any of us to talk. Education made the jatishovvo (civilized), now we (the community) can talk to city-people like you, and drink only during festivals. (Discussion at Khaspara, Rajshahi, September 15, 2019) 
Unexpectedly, everyone agreed. Shiris Munda (45) tried to explain the 'value of education' as 'Educated people never shout while talking to others, they speak politely, they stay clean and wear clean (clothes).' Likewise, Biloti Munda (32) considered the possibilities of education as a remarkable step forward in their livelihood and a tool to safeguard themselves from cheating. She also stated that if a mother is educated, she can instil good manners in their children and can monitor school homework.

Here, it is noteworthy that the educational paradigm has instilled a sense of inferiority among the Adivasi rendering them as 'uncivilized'- indicating the colonial legacy of the cultural politics in the region. The Adivasi parents' primary concerns about education were not as a qualification to get a secure salaried job or upliftment of their economic condition, rather they tended to characterize the educated person as polite, sensible, and aesthetic. They valued three kinds of skills related to education: the writing skills - to write one's name, speaking skills - to communicate properly with 'the city people', and finally, numeracy skills - to avoid being cheated.

\section{Navigating cultural politics and scarcity}

Being in a perceived inferior status, the Adivasi people must face cultural politics in the locality where scarcity of employment opportunities bring the divide among the different segments of the population. Subarna Munda (23), who had a bachelor's degree, wanted to be a teacher at government primary school in the village. She was among the few in her community to be able to pursue her studies. Humiliation at college on the first day, with the surname 'Munda' made her realize, only education can free her from those prejudices attached with her identity. Before completing her studies, she worked for a local NGO early in her college days.

Even though she had the required qualifications for being a primary school teacher, her experiences from college days made her realize, that it would not be easy to get the job. Her uncle Pravat Munda (50), a member of the school managing community in his locality, took the responsibility to arrange a meeting with the local MP to get assistance in this regard. Subarna had gone through the interview procedure and was listed for candidacy. She waited for the final call from the school authority. But later, she heard that a candidate from the Bengali Muslim community had been selected for the post. She believed, she did not get the job, because of not being able to bribe, establishing connections/securing 
recommendations from high ranked government officials required. Subarna felt, she could not compete with the Bengali Muslim community.

Now, she hopes to be a village doctor, presently working as the assistant of one. Subarna Munda, who wishes to marry someone well-established, is now facing difficulties, as no one is qualified enough. It is interesting to note that after realising that she would never become a teacher, and her marriage would be uncertain, her aspirations adjusted to the new situation.

\section{Choosing not to wait for a miracle}

The current education policy of Bangladesh, as mentioned earlier, is to provide pre-primary compulsory education for all children and to promote equality. The government has introduced free education and scholarships for female students and provides special quotas for all Adivasi students to enter public universities. However, it does not materially improve the scenario. 'Free education' provides books and exemption of monthly tuition fees for both boys and girls in public school up to secondary level. The parents need to supply school dresses and other essentialities for their children. The Santal often get support from the Christian missionaries. But the Munda need to rely on loans from NGOs or local moneylenders.

Young Munda children, who are keen to study, save money when they migrate for approximately one month (from early January to early February) to nearby early Boro paddy growing regions in the dry season. The crops are entirely deeptubewell fed and need to be transplanted on time, which means an increased demand for labour. The season gives additional earnings especially for the young, who can spend a part of it to fulfil educational needs. However, with persistent stereotypical barriers ahead, for example - inferior treatment from peers, and at times, even from teachers, these people are left off even more vulnerable than before and they lose the desire to study further.

The politics of scarcity made the Adivasi lose interest in wasting time for longterm general education. They think that the ongoing education system is timeconsuming and is not accelerating for direct income-generating activities. Among the Munda children who do not do well in studies or show less enthusiasm, their parents try to engage them as 'mashohari' (monthly basis wage labourer) in Muslim property owners' homes or with other non-agricultural jobs at the shops of the bazaar. The indigenous people believe that a well-paid, white-collar job, 
might as well be considered a miracle. Hence, many do not wait for the miracle, and with the demand of labour increasing, most parents want to involve their son with agricultural activities after finishing primary education.

\section{Aspirations of a 'Good Life' and Overcoming Structural Limitations}

The following ethnographic stories focus on the educational experiences and aspirations of young Santal and Munda people. These stories show how they transform the idea of education in their own way to fulfil the aspirations of their life.

The following discussion is premised in line with a different setting, for, as Fischer (2014) ethnographically explained, Mayan farmers engaged with the market to pursue their own visions of 'good life'. He argued that 'good life' is not a state to be obtained but an ongoing aspiration for something better that gives meaning to life's pursuit. Fischer (2014) mentioned that in rural Guatemala, such aspirations involved increasing incomes - to pay for children's education, to buy land to ensure economic security, and to expand the range of 'what is possible' but were no less morally driven. Moreover, he demonstrated that aspiration alone was not sufficient to effect change. It also had to have a way, the space to operate among a range of substantive opportunities. In Guatemala, the market for highend, high-altitude coffee opened new opportunities for smallholding Mayan farmers and provided a new source of hope. They had no illusions that the opportunities of this new market were perfect or even fair; yet they overwhelmingly valued the choice and the expanded agency in their quest to construct a better future.

Similarly, the ethnographic insights below will illustrate that indigenous communities are not passive in terms of being marginalized with the disadvantages of the socio-political environment. Rather, they actively look to transform their situation.

\section{Community effort for institutional education}

One day in March, after lunch down the streets of Chanduria village, a conversation with one of the Santals informed about a meeting to be held in Babuldanga, in the residence of 'Majhi', the leader of the Santal community. The topic of this meeting was one preschool, run by a local NGO. That kindergarten happened to be the only preschool in a $1.5 \mathrm{~km}$ radius from either village. However, with NGO funding closed, the school was recently forced to shut down. 
With public elementary schools starting for kids aged around 7 years, this preschool provided these kids the best chance to pursue further education, beginning with admission to public schools. But, with no funds, and teachers without a salary, the school was on the way for permanent shutdown.

Hence, the locals, mainly parents, are on their way to Majhir Bari to discuss the future of the institution. The parents certainly did not want this to happen and were even willing to pay tuition fees for the existence of the kindergarten. Without this, the education of so many kids would be uncertain, leading to troubles in studying, eventually proving difficult to be admitted to public elementary schools.

This story reveals the ambition of Santal parents to reopen the preschool. It is mentioned that most of the Santals are landless and they work as wage labourers within the agricultural economy. In this context it is obvious that they may not be investing their modest gains in their children's schooling. But the scenario is quite different here. The parents came to the common decision that they want the school to operate for their children's sake even at their own expense. This story also resembles community consciousness towards education which seems to drive them to look for alternative paths to reopen the school.

\section{Aspirations across generations}

Shefali Hembrom (30), the mother, just reached home from work in the field. At the same time her daughter, Nitu - a student of class VIII, hurries home from school. They clean themselves up hastily by the tube well. Nitu continues to urge her mother to be quicker so as not to be late in the Parents' Day meet at her school. Nitu - in a conversation has expressed her dream of becoming a nurse. Her mother was quite anxious of Parent's Day, eager to learn about her daughter's progress in school. With hopes high for her daughter, she was keen on listening to how her daughter is performing.

Nitu dreams of being a nurse. When asked why, she told us the success stories of two girls in this profession that inspired her to join this profession. She also said that, recently, two girls from her village got a housekeeping job in the United Kingdom through the church. Before going they pursued a year-long housekeeping course in Rajshahi. They are now sending money to their family. For Nitu, these success stories generated a view of 'good life' towards which she was striving for. 
Nitu's mother Shefali was withdrawn from school by her parents. She recalled the time and told that, in the past most left school before or upon completion of primary school and had marriages arranged 3-4 years later. She could complete class VI as she belonged to a household with landed wealth. She had a wish to become a teacher. Without her parents she could not fulfil her wish. Now she is happy that her daughter, Nitu is studying 'extremely hard' to fulfil her dream.

The mother-daughter story shows that schooling in general is positively valued by both the parent and the girl. To them, education represented the possibility of a better life outside household chores. The success stories of a nurse in the city or a migrant job in a foreign country amplified the hope of many girls in the community. Nitu's zeal for education can be marked as a new awareness to pass over the social-cultural barriers.

\section{Role of expanded social capital}

Nibesh (25), a young Santal, just acquired a job in the Police. But the journey to this post has been a rough one. Nibesh, son of a day labourer, lost his father 15 years ago at the age of 10 . With no owned property, along with his two brothers and two sisters, his mother took the responsibility of their family. At that time, his elder brother, who passed $10^{\text {th }}$ grade, got a job as a daily wage labourer in a dockyard in Mongla port, Khulna. His brother used to send money for household expenses. His mother jointly share-cropped 10 bighas $^{12}$ of land with his uncle. Nibesh was good at studies and with the help of the church he went to missionary school. His younger brother followed him, now a student of class 12, is studying in the Notre Dame College of Dhaka. Nibesh's two sisters are married in a distant village. Both continued their studies till the higher secondary level.

From this story it can be concluded that Nibesh's family was able to invest agricultural profits and his migrant brother's income into education. The social mobility of Nibesh's elder brother made the difference, turning the household economically solvent. Nibesh's education in a missionary school enabled him to connect with the outside world and his 'new knowledge' enabled him to exploit close social links with local government officials - a form of social capital, i.e., social relationships (Coleman, 1990) that can be mobilized in overcoming the ethnic identity-based majority-minority divide. In this case, he has turned to his social network to attain his job in the police force. 


\section{Different measures of success}

The discussion with Madhab Munda (30), a teacher of an NGO-run primary school, began in a tea stall in the village - that he often visits. He lives with his mother and two brothers. His brothers worked as day labourers. Madhab used to work as a garment worker in a factory, previously, at Dhaka. After his father's death he left the job and returned home. In conversation with him about Munda education, the rise of NGO education in the locality for Adivasi and the promises it offers were identified. Madhab opined, that the possibility of a better life with economic stability, convinced the Munda to keep their children to continue. Madhab had hopes of getting a white-collar job, which did not materialize. But he does not see this as a failure, but rather, a path to personal and social transformation. For him, being educated means to pose a challenge to the hegemonic assumption of Bengalis that Munda are fit only for manual labour. Madhab sees education as a way to escape from derogatory remarks.

While examining the narratives of education, a varied set of related Santal and Munda discourses can be found. These narratives help in structuring how the young and elderly Adivasi think about schooling, identity, and success. Nevertheless, the Santal and the Munda, both conceptualize education as overcoming degrading connotation - 'savage and backward' attached to them. They had a desire among to portrait a positive image of themselves to encounter the negative one. To see education as a tool to 'civilize' is a common discourse among these communities - a response to the overall cultural politics.

Though most parents and the young perceive schooling to create individual confidence, and prosperity and assess the qualifications, skills, and credentials that it provides, in line of improving a household's economic position and generating 'social capital', for them it is also about identity, whereas it is seen as a 'weapon of the weak' (cf. Scott, 1985) within ongoing social struggles against poverty and oppression.

Higher education is often evaluated as a hope for a 'salaried job', outside agricultural labour, or being a nurse, a schoolteacher, or an overseas migrant worker. But the Santal and the Munda communities did not feel confident to invest enough time on it due to the lack of opportunities in the economic sphere, and uneven competition against Bengali competitors. In other words, lack of social, cultural, or economic capital hinders the ordinary villagers to possess such a secure position - a form of graduated sovereignty having colonial past (Ong, 2000). 
Finally, the process of objectification through colonial administrative account, identity politics, and everyday practices of untouchability continue to reproduce their marginality. The situation attests, that in no way can certificates of education erase or replace the label that was forced upon them (Jeffrey et al., 2004).

However, ethnographic examples demonstrate that the Santal and the Munda aspire for a future influenced by the overall circumstances (Appadurai, 2004). Nonetheless, the life stories reveal, the Adivasi, even though marginalized in the overall sociality, manoeuvre with the existing resources, and aspire for a 'good life'. This, above all suggests that it is pertinent to focus on the life of the marginalized communities and develop an understanding of what education means to them.

\section{Conclusion}

Besides structural limitations in accessing education, what matters most for the Adivasi is the life after few years of education. Adivasi parents repeatedly mentioned, they used to hope their children will get salaried employment through schooling. Over the years, as many from the locality have failed to reach their aspirations, hopelessness has graved in. They sometimes prefer to engage in household economic activities. At times, economic vulnerability forces them to drop out, and simultaneously many young people have simply lost interest in pursuing education. It is not that they do not have the aspirations of economic development, rather aspirations of a good life provoke them to drop out. Promoting social inclusion at the margin of the society will require comprehensive economic and social policies.

This article puts forward two arguments: firstly, affirmative actions that support education for all ironically widen the discrimination and marginalization, as the philosophy behind education carries colonial legacy of dividing the society into dominating and dominated segments, and the Adivasi were ever since at the wrong side of this divide. Secondly, the major concern was with the zeal of the Adivasi. The different perspectives on education that could be learnt from the Adivasi make it clear that people at the margin, i.e., the Adivasi have the capacity to navigate towards a 'good life'. They are not passive in the face of unfavourable social conditions. They work their way towards a life they desired and continuously reorient themselves, navigating through their marginal state in cultural politics and graduated sovereignty - the aspect conventionally ignored in the Adivasi 
discourses. This article proposes - formal education and development planning do not always produce the intended results due to the pervasiveness of cultural politics inherent in the cultural milieus of Barind, but the Adivasi strategically work towards a good life - capable of augmenting change for the better.

Empirically the article shows, formal education does not necessarily lead to convertible skills for the Adivasi in terms of direct economic return. This trend is reinforced by their lower status in the broader cultural context. Nonetheless, Adivasis are using education in overturning their cultural inferiority, as well as navigating cultural politics and scarcity. Education gives them hope not to wait for a miracle and they use different measures of success of/through education, such as: a path to personal and social transformation and escape from derogatory remarks. Thereby, education, even if does not result into direct employability, it is a major tool for the Adivasi in the cultural contexts of socio-economic marginalization. Therefore, in formulating policies governing formal education for the marginal population, it should be considered that education could have diverse meanings that not necessarily relate to employability. Nonetheless, since 'availability, affordability, and accessibility' of education will not guarantee increased participation of the Adivasi, renewed efforts must be taken so that Adivasis could overcome the minority-majority divide and their inferior sociocultural status in the Barind and thereby, benefit more from formal education.

\section{Acknowledgements}

This article is part of a research project titled 'Marginalization and Discrimination in Education: Situation Analysis of the Ethnic Minority Groups in Barind Region of Bangladesh'supported by funding from Government of the People's Republic of Bangladesh, Ministry of Education, Bangladesh Bureau of Educational Information \& Statistics (BANBEIS) and Grant of Advanced Research in Education (GARE).

\section{Notes}

1. The government of Bangladesh did not ratify the ILO convention 169, the constitutional identity recognized them as Indigenous or Adivasi.

2. Much work in this line of argument was not found in Bangladesh. Several recent publications from scholars (for example Vermeulen, 1999; Froerer, 2015) working in India helped us to familiarize such kinds of theoretical arguments. 
3. The project was renamed the Barind Multipurpose Development Authority (BMDA) in the early 1990s and now covers a large part of the Barind Tract.

4. The eighteen ethnic groups are the Santals, Oraons, Mundas, Malpahariers, Gainjhus, Kochas, Malos, Mahalis, Mahatos, Bhumijs, Tures, Bhuyasors, Choudhurys, Musaharas, Kolkamaras, Kuruks, Ho and Rajbansis. These ethnic groups speaking over ten languages and dialects; most of these languages belong to the Austro-Asiatic, Dravidian, and Indo-European linguistic families.

5. To the 1991 census, the Santal population was over two hundred thousand (Islam (ed), 2012).

6. An unofficial record published by private agencies and local NGOs in 1995 estimated the total Munda population at 35,000.

7. The Santal and the Munda settled in the Barind region as migrant labours (adhiar). The Adivasi, 'as a migrant adhiar' (half-sharer), were verbally entitled to land by their Zamindars. After the permanent settlement act, as land became private property - an idea alien to them, did not bother them to go to the tahshil office for the land registration paper. The new private ownership law took away the right to land from the Adivasi. And thus, the beginning of the process of marginalization started.

8. The most recent policy in Bangladesh, the National Education Policy 2010, attempted to address inclusive education. The aim of this policy is, among others, to promote the culture and language of small ethnic groups. In preprimary and primary stages, it is essential to take necessary steps for education in their respective mother tongue, teachers from the Adivasi community and appropriate textbooks for indigenous children. In Adivasi inhabited areas, establishing primary schools with residential facilities have been promised. For further details please see: Education for all: National Plan of Action-II, 2003-2015 and for analysis see Ahsan and Burnip, 2007.

9. The British Government officials happened to be the only source of information for the Adivasi of Bangladesh for a long. During the PostBritish period (1947-1971), reproductions of the older sources were mostly compiled. Several academic articles by foreign academics from the disciplines of sociology and anthropology were published. However, these books or articles were not available in the country. In contrast, popular writings were easily available, mostly by amateur writers, eventually 
becoming a source of academic write up for influential writers and even for textbook information.

10. www.earlyeducationbd.xyz

11. www.englishfor2day.com

12. 10 Bigha $=4$ acres (approximately)

\section{References}

Ahsan, M. T., \& Burnip, L. (2007). Inclusive education in Bangladesh. Australasian Journal of Special Education, 31(1), 61-71.

Ahsan, M. T., \& Mullick, J. (2013). The journey towards inclusive education in Bangladesh: Lessons learned. Prospects, 43, 151-164.

Ali, A. (1998). Santals of Bangladesh. Dhaka: Institute of Social Research \& Applied Anthropology.

Ali, A., \& Shafie, H. (2005). Entitlement and Deprivation: Selected Cases of Discrimination in Bangladesh. Dhaka: UNESCO.

Appadurai, A. (2004). The capacity to Aspire: culture and the terms of recognition. In V. Rao and M. Walton (Eds.), Culture and Public Action (pp. 59-84). Stanford: Stanford University Press.

Barkat, A., Haque, M. M., Osman, A., \& Halim, A. (2009). Life and Land of Adibashis: Land Dispossession and Alienation of Adibashis in the Plain Districts of Bangladesh. Dhaka: Pathak Shamabesh.

Bates, C. (1995). Race, caste and tribe in central India: The early origins of Indian anthropometry. In P. Robb(Ed.), The Concept of Race (pp.219-59). New Delhi: Oxford University Press.

Begum, H. A., Parveen, R., \& Chakma, E. (2018). The challenges of geographical inclusive education in rural Bangladesh. International Journal of Inclusive Education, 23(1), 7-22.

Ciotti, M. (2006). In the past we were a bit 'Chamar': Education as a self-and community engineering process in northern India. Journal of the Royal Anthropological Institute, 12, 899-916.

Cohn, B. S. (1968). Notes on the history of the study of Indian society and culture. Structure and Change in Indian Society (pp. 3-28). University of Chicago: Committee on Southern Asian Studies.

Coleman, J. S. (1990). Foundations of Social Theory. Cambridge, Massachusetts: Harvard University Press.

Debnath, M. K. (2011). Living on the Edge: The Predicament of a Rural Indigenous Santal Community in Bangladesh. Ph.D. Thesis, Ontario Institute for Studies in Education: University of Toronto. Retrieved from http://hdl.handle.net/1807/26415(Accessed on January 14, 2021).

Dhamai, B. M. (2014). An overview of indigenous peoples in Bangladesh. In M. S. Chowdhury (Ed.), Survival under Threat: Human Rights Situation of Indigenous Peoples in Bangladesh,(pp.10-26). Dhaka: Asia Indigenous Peoples Pact and Kapaeeng Foundation.

Drèze. J., \& Sen, A. (2013). An Uncertain Glory: India and Its Contradiction. Princeton: Princeton University Press.

Duflo, E. (2012). Women empowerment and economic development. Journal of Economic Literature, 50(4), 1051-1079.

Evans, M. (1998). Behind the rhetoric: The institutional basis of social exclusion. IDS Bulletin, 29(1), 41-49. 
Fischer, E. (2014). The Good Life: Aspiration, Dignity, and the Anthropology of Wellbeing. California: Stanford University Press.

Foucault, M. (1972). The Archaeology of Knowledge and the Discourse on Language. Translated by A. M. Sheridan Smith. New York: Pantheon Books.

Froerer, P. (2012). Learning, livelihoods, and social mobility: Valuing girls' education in Central India. Anthropology and Education Quarterly, 43(4), 344-357.

Froerer, P. (2015). Adivasi young people and the risk of education in rural Chhattisgarh. South Asian Hist. Cult., 6(3), 365-379.

Haan, A. (1998). Social exclusion: An alternative concept for the study of deprivation. IDS Bulletin, 29(1), 10-19.

Halim, S. (2015). Land Loss and Implications on the plain land Adivasis. In Shanghati (pp. 72-89), Bangladesh Indigenous Peoples Forum.

Islam, M. S. (2004). Minority Groups and NGOs in Northwestern Bangladesh: An Anthropological Study of the Santal and the Oraon (Unpublished Masters Thesis), Hong Kong: The Chinese University of Hong Kong.

Islam, M. R. (2014). Culture, Economy, and Identity: A Study of Oraon Ethnic Community in the Barind Region of Bangladesh. PhD Thesis, James Cook University. Retrieved from https://researchonline.jcu.edu.au/41601/1/41601-islam-2014-thesis.pdf (Accessed on January 14, 2021).

Islam, S. (Ed.) (2012). Banglapedia: National Encyclopaedia of Bangladesh. Dhaka: Asiatic Society of Bangladesh.

Jeffrey, C, Jeffery, R., \& Jeffery, P. (2004). Degrees without freedom: The impact of formal education on Dalit young men in North India. Development and Change, 35(5), 963-986.

Kumar, K. (2005). Political Agenda of Education: A Study of Colonialist and Nationalist Ideas. New Delhi: Sage Publications.

Latif, S. (2004). Improvements in the quality of primary education in Bangladesh, 1990-2002. Paper commissioned for the EFA Global Monitoring Report 2005. Retrieved from http://citeseerx.ist.psu.edu/viewdoc/download?doi=10.1.1.525.263\&rep=rep1\&type=pdf (Accessed on September 15, 2020).

Macias, J. (1996). Introduction: Racial and ethnic exclusion: A problem for anthropology and education. Anthropology \& Education Quarterly, 27(2), 141-150.

Macpherson, C.B. (1962). Political Theory of Possessive Individualism. Oxford: Oxford University Press.

Macpherson, C.B. (1977). The Life and Times of Liberal Democracy. Oxford: Oxford University Press.

Mannheim, K., \& Stewart, W.A.C. (1962). An Introduction to the Sociology of Education. London: Routledge and Kegan Paul.

Manusher Jonno Foundation (MJF). (2016). State of the Marginalized Communities in Bangladesh. Dhaka: Manusher Jonno Foundation.

Minj, A., \& Khakshi, J. W. (2015). Mapping BRAC Development Activities Relating to Indigenous Peoples. BRAC: Integrated Development Programme.

Moore, H. (1990). Visions of the good life: Anthropology and the study of utopia. Cambridge Anthropology, 14(3), 13-33.

Ong, A. (2000). Graduated sovereignty in South-East Asia. Theory \& Culture \& Society, 17(4), 55-75. 
Roy, S. C. (1912). The Mundas and their Country. Jogendra Nath Sarkar: City Book Society.

Sarker, P., \& Davey, G. (2009). Exclusion of indigenous children from primary education in the Rajshahi Division of Northwestern Bangladesh. International Journal of Inclusive Education, 13(1), 1-11.

Scheper-Hughes, N. (1992). Death without weeping: the violence of everyday life in Brazil. Berkeley: University of California press.

Scott, J. (1985). Weapons of the Weak: Everyday Forms of Peasant Resistance. USA: Yale University Press.

Sen, A. K. (2001). Development as freedom. Oxford, UK: Oxford University Press.

Shafie, H., \& Kilby, P. (2003). Including the excluded: Ethnic inequality and development and the Northwest of Bangladesh. Labour and Management in Development, 4(3), 1-15.

Sharif, S. (2014). Education and skill development of Santal children and youth in Bangladesh. Bangladesh Education Journal, 13(1), 7-26.

Sharmeen, S. (2013). In the name of 'underdeveloped' Adibashi: the politics of NGOs and the Munda in Bangladesh. Development in Practice, 23(8), 1052-1062.

Sharmeen, S. (2014).The politics of irrigation: Technology, institution and discourse among the Munda in Barind, Bangladesh. Journal of South Asian Development, 9(1), 49-70.

Sharmeen, S. (2015). History, collective memory, and identity: The Munda of Barind region, Bangladesh. Anthropos, 110(1), 1-9

Skaria, A. (1997). Shades of wildness: Tribe, caste, and gender in Western India. The Journal of Asian Studies, 56(3), 726-745.

Sundar, N. (2010). Educating for inequality: The experiences of India's 'Indigenous' citizens. Asian Anthropology, 9, 117-142.

Timm. F. R. W. (1991). The Abivasis of Bangladesh. London: Minority Rights Group.

Walsh, J. E. (1983). Growing Up in British India. New York: Holmes and Meier. 